DOI

\title{
ОСОБЛИВОСТІ АНЕМІЧНОГО СИНДРОМУ ЯК ПРОЯВУ ТРОФОЛОГІЧНОЇ НЕДОСТАТНОСТІ ПРИ ХРОНІЧНОМУ ПАНКРЕАТИТІ НА ТЛІ ІШЕМІЧНОӤ ХВОРОБИ СЕРЦЯ
}

\author{
○Л. С. Бабінець, Н. А. Мельник, Л. С. Цибульська, М. В. Скрипник
}

ДВНЗ «Тернопільський державний медичний університет імені І. Я. Горбачевського МОз Украӥни»

РЕЗЮМЕ. У роботі представлені особливості анемічного синдрому та зміни трофологічного статусу у хворих на хронічний панкреатит із супутньою ішемічною хворобою серця, а також досліджено взаємозв'язок між параметрами трофологічного статусу та показниками анемії у таких хворих.

КЛЮчОВІ СЛОВА: хронічний панкреатит, ішемічна хвороба серця, анемічний синдром, трофологічна недостатність.

Вступ. При хронічному панкреатиті (ХП) виникає порушення балансу між надходженням нутрієнтів (харчових речовин) в організмі хворого і його потребами в них. Формується полінутрієнтна недостатність [1]. При ХП дефіцит харчових речовин виникає як за екзогенним варіантом, так і за ендогенним $[2,6]$. Виникає і за певних умов поглиблюється трофологічна недостатність (ТН), яка характеризується синдромами дефіциту енергії, білка, вітамінів, мікроелементів і електролітів [3]. На тлі прогресуючої функціональної недостатності підшлункової залози і поглиблення ТН вичерпуються запаси нутрієнтів у тканинах, що спочатку веде до біохімічних і функціональних змін, а надалі проявляється численними та складними клінічними симптомами $[4,5]$. ХП сприяє прогресуванню ТН, яка проявляєТься зниженням маси тіла, розвитком анемічного синдрому (АС), остеодефіциту, імунодефіциту [6]. Встановлено, що АС у хворих на ХП $\epsilon$ маркером тяжкості захворювання та предиктором резистентності його до лікування. Оскільки всмоктування заліза здійснюється у верхніх відділах тонкої кишки, а його засвоєння визначається рівнем абсорбції переважно у дванадцятипалій кишці і проксимальних відділах тонкої кишки, то у хворих на ХП має місце симптоматика залізодефіциту (від латентного дефіциту заліза до легкої, середньої та в деяких випадках і до тяжкої залізодефіцитної анемії) [7].

Мета дослідження - вивчити особливості і характер АС та зміни трофологічного статусу (TC) у хворих на ХП із супутньою ішемічною хворобою серця (IXC), а також дослідити взаємозв'язок між параметрами ТC та показниками анемії у таких хворих.

Матеріал і методи дослідження. Всіх паці-

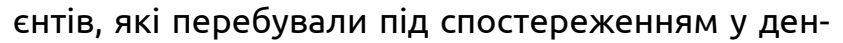
ному стаціонарі Тернопільської міської лікарні № 2, було поділено на дві групи: 20 хворих на ХП та 32 хворих на ХП в поєднанні з ІХС (стабільна стенокардія напруги, I-ІІ функціональний клас). Джерелом інформації слугували «Медичні карти стаціонарного хворого» (ф. 003/о). Серед про- аналізованих хворих було 27 жінок і 25 чоловіків. Переважали пацієнти працездатного віку. Контрольна група складалася з 20 практично здорових осіб. У дослідження не включали пацієнтів із гострими формами IXC в анамнезі, цукровим діабетом середнього та тяжкого ступенів, що вимагає прийому інсуліну, артеріальною гіпертензією II i III ступенів та тяжкими супутніми захворюваннями. Діагноз ХП верифікували згідно із загальноприйнятими в клініці критеріями [8]. Діагноз IXC встановлювали згідно із рекомендаціями міжнародної класифікації хвороб 10 перегляду, відповідно до класифікації, яка була затверджена на VI Національному конгресі кардіологів України (2000) та наказом МО3 України № 54 від 14.02.2002. Функціональний клас стенокардії напруги встановлювали за класифікацією стенокардії Канадської асоціації кардіологів (1976). Для оцінки ТС хворих на ХП використовували визначення наступних антропометричних показників [3]. Індекс маси тіла (IMT) визначали за формулою (1):

$$
\begin{aligned}
& \text { IMT = M / } \mathrm{P}^{2} \text {, } \\
& \text { де } \mathrm{M-маса} \mathrm{тіла,} \mathrm{кг;} \\
& \text { Р- зріст, м. }
\end{aligned}
$$

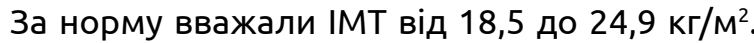
Запаси жиру в організмі визначали шляхом вимірювання шкірно-жирової складки над трицепсом (ШЖСТ). Значення ШЖСТ менші 9,5 мм у чоловіків і 13 мм у жінок вказували на енергетичну недостатність. Про соматичний пул білка судили за окружністю м'язів плеча (ОМП), яку визначали за формулою (2):

ОМП = ОП -0,314 $\times$ ШЖСТ,

де ОМП - окружність м'язів плеча, см;

ОП - окружність плеча, см;

ШЖСТ - шкірно-жирова складка над трицепСом, MM.

Нормою вважали ОМП не менше 23 см у чоловіків та $21 \mathrm{~cm}$ - у жінок [3]. Для оцінки АС використовували визначення наступних лабораторних показників обміну заліза за загальноприйнятими методиками. Сироваткове залізо (3С), феритин (ФС) та трансферин (ТС) - нормальні значення 
Огляди літератури, оригінальні дослідження, погляд на проблему

яких становили відповідно: 6,6-26,0 мкмоль/л для жінок та 10,6-28,3 мкмоль/л - для чоловіків; 10,0-147,0 мкмоль/л - для жінок та 22,0346,0 мкмоль/л - для чоловіків; 2150,0-3800,0 г/лдляжіноктачоловіків.Загальна залізозв'язувальна здатність сироватки (333С) - нормальні показники 49,0-69,0 ммоль/л. Розрахунок латентної залізозв'язувальної здатності сироватки (ЛЗ3С) проводився за формулою (3):

л33С $=333 \mathrm{C}-3 \mathrm{C}$,

в нормі цей показник складає 32,046,0 ммоль/л. Для визначення насиченості трансферину залізом (НТ3) використовували таку формулу (4):

HT3 = 3C / 333C, нормальні значення цього показника - 16,0$50,0 \%$. Рівень гемоглобіну (HBG) визначали фотометричним методом, а кількість еритроцитів (RBG) в крові - рутинним методом. Нормою вважали не менше ніж 120 г/л для чоловіків i 110 г/л для жінок та 4,0-5,0×1012 л $^{-1}$ для чоловіків і 3,7-4,7×1012 $\pi^{-1}$ для жінок відповідно [9]. Статистична обробка отриманих даних виконувалася на персональному комп'ютері з використанням стандартних пакетів програм Microsoft Excel та за допомогою комп'ютерної програми Statistica for Windows версії 6.0 (Stat Soft inc., США).

Результати й обговорення. Були проаналізовані антропометричні показники, за якими судили про запаси жиру і соматичний пул білка, як маркери ТС (табл. 1).

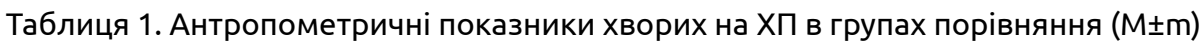

\begin{tabular}{|c|c|c|c|}
\hline Показник & Група контролю $(\mathrm{n}=20)$ & $\begin{array}{c}\text { Хворі на XП } \\
(\mathrm{n}=20)\end{array}$ & $\begin{array}{c}\text { Xворі на XП+IXC } \\
(n=32)\end{array}$ \\
\hline $\mathrm{IMT}, \mathrm{k} \Gamma / \mathrm{M}^{2}$ & $22,30 \pm 0,32$ & $\begin{array}{c}25,09 \pm 1,23 \\
(p<0,05)^{*}\end{array}$ & $\begin{array}{c}30,28 \pm 0,99 \\
(p<0,01)^{*} \\
(p<0,01)^{* *}\end{array}$ \\
\hline ШЖСТ, мм & $11,81 \pm 0,29$ & $\begin{array}{c}16,10 \pm 0,72 \\
(p<0,05)^{*}\end{array}$ & $\begin{array}{c}19,24 \pm 0,69 \\
(p<0,001)^{*} \\
(p<0,001)^{* *}\end{array}$ \\
\hline OМП, см & $27,78 \pm 0,25$ & $\begin{array}{c}22,72 \pm 0,39 \\
(p<0,01)^{*}\end{array}$ & $\begin{array}{l}23,17 \pm 0,49 \\
(p<0,001)^{*} \\
(p<0,05)^{* *}\end{array}$ \\
\hline OT, CM & $77,75 \pm 0,32$ & $\begin{array}{c}78,90 \pm 3,31 \\
(p<0,05)^{*}\end{array}$ & $\begin{array}{l}90,10 \pm 2,6 \\
(p<0,001)^{*} \\
(p<0,05)^{* *}\end{array}$ \\
\hline
\end{tabular}

Примітки:

1. * - вірогідна відмінність стосовно групи контролю;

2. ** - вірогідна відмінність стосовно хворих на ХП.

У значної частини обстежених хворих відмічали розлади живлення. Встановлено, що у групі Хворих на ХП+ІХC середнє значення IMT було на 21 \% вищим такого в групі ХП. У хворих на ХП показник IMT становив $(25,09 \pm 1,22) \mathrm{kr} / \mathrm{M}^{2}$, а у групі хворих на ХП+ІХC - $(30,28 \pm 0,99) \mathrm{kr} / \mathrm{M}^{2}$ і був достовірно вищий відносно групи контролю в обох порівнюваних групах. Зокрема, у групі хворих на $X П+I X C$ із нормальною масою тіла та із надлишком ваги було 6 (18,75 \%) і 8 (25 \%) відповідно проти 12 (60\%) та 4 (20\%) таких хворих у групі ХП. У $18(56,25 \%)$ хворих із ІХС було виявлено ожиріння різного ступеня тяжкості: І ст. - у 7 (21,88 \%), ІІ ст. у 11 (34,37\%). У групі ХП хворих із ожирінням I ст. один хворий, з ожирінням ІІ ст. - 3 (15\%).

Було встановлено, що товщина ШЖСТ у групі Хворих на XП+IXC була вищою, ніж у групі хворих на ХП, і свідчила про надлишок запасів жиру. Середній показник ОТ був достовірно вищим у хворих на ХП, порівняно із групою контролю, проте слід зазначити, що ОТ у хворих із супутньою IXC вказував на абдомінальну форму ожиріння. У той же час відмічалося достовірне зниження показника ОМП в групі XП+IXC, порівняно із групою контролю, що свідчило про збіднення соматичного пулу білка (скелетних м'язів). Таким чином, надлишок маси тіла в групі хворих на ХП в поєднанні з IXC відбувався за рахунок жирових надлишків при деякій втраті білка.

Про збіднення вісцерального пулу білка свідчило встановлення достовірно нижчого рівня показників НGB у хворих на XП+IXC, порівняно із групою хворих на ХП: $(102,34 \pm 2,84)$ г/л проти $(120,05 \pm 4,31)$ г/л. Також виявлено розвиток анемії легкого та середнього ступенів у 24 (75\%) хворих на ХП+ІХС проти 10 (50 \%) - без IXС. Легкий ступінь анемії у Хворих групи XП+ІХС стосовно групи ХП відмічався у 8 (25\%) проти 6 (30\%) хворих, середній ступінь тяжкості -у 16 (50\%) проти 4 (20\%) хворих (рис. 1, 2). 
Огляди літератури, оригінальні дослідження, погляд на проблему

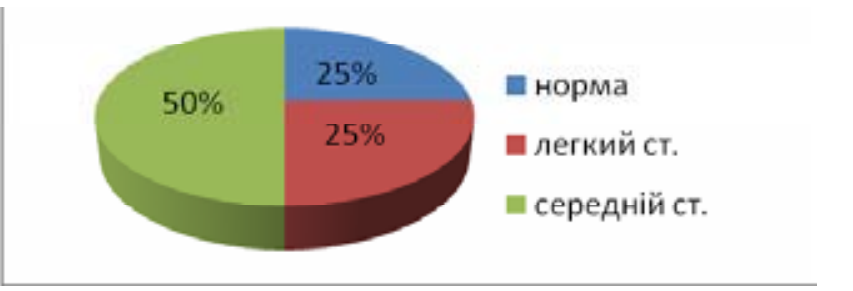

Рис. 1. Розподіл хворих на ХП+ІХС за ступенем тяжкості анемії.

Що стосується показників обміну заліза В групі ХП+ІХC, то аналіз отриманих даних виявив достовірне зниження рівня RBC (чол. $(3,25 \pm 0,12) \times 10^{12} \pi^{-1} ; \quad$ жін. - $\left.(3,23 \pm 0,09) \times 10^{12} \pi^{-1}\right)$, 3 (чол. - $(11,67 \pm 0,91)$ мкмоль/л; жін. $10,58 \pm 1,48)$ мкмоль/л), НТЗ (чол. - $(18,16 \pm 2,14) \%$; жін. - $(15,11 \pm 2,34) \%)$ ФС (чол. - $(131,31 \pm$ $33,01)$ мкмоль/л; жін. - $(62,81 \pm 16,25)$ мкмоль/л) та достовірне збільшення рівня 333С (чол. $(68,13 \pm 2,19)$ ммоль/л; жін. - $(71,19 \pm 1,42)$ ммоль/л), ЛЗ3С (чол. - $(56,46 \pm 2,91)$ ммоль/л; жін. $(60,62 \pm 2,44)$ ммоль/л), ТС (чол. - $(5322,02 \pm$ $161,71)$ г/л; жін. - $(5179,92 \pm 197,21)$ г/л) як у чоловіків, так і у жінок, порівняно з показниками контрольної групи. Аналізуючи показники обміну заліза в групі ХП ми також відмітили достовірне зниження рівня RBC, 3C, НT3, ФС та достовірне збільшення рівня 333С, ЛЗ3С, ТС як у чоловіків, так і у жінок стосовно таких показників контрольної групи. Отримані результати довели наявність тенденції до формування АС залізодефіцитного характеру як у групі хворих на ХП у поєднанні із IXC, так і у групі хворих на ХП без IXC.

Аналіз коефіцієнтів кореляції між ШЖСТ, ОТ та кількістю еритроцитів у крові хворих групи ХП+ІХC вірогідно засвідчив наявність помірних обернених кореляційних зв'язків між вищеназваними антропометричними показниками та кількістю RBC ( $r=-0,35$ і $r=-0,36$ відповідно). Також

\section{ЛІТЕРАТУРА}

1. Бабінець Л. С. Досвід застосування теравіту для корекції трофологічного статусу при хронічному панкреатиті//Збірник наук. праць співробітників КМАПО ім. П. Л. Шупика. - Київ, 2008. - Вип. 14, книга 1. - С. 297-230.

2. Андрейчин С. М. Сучасні уявлення про метаболічну ендогенну інтоксикацію / С. М. Андрейчин, Т. О. Голомша // Інфекційні хвороби. - 2012. - № 1. - С. 84-87.

3. Буклис Э. Р. Трофологическая недостаточность при болезнях органов пищеварения // Клин. перспективы гастроентер., гепатол. - 2004. - № 2. - С. 10-15.

4. Залінська О. М. Дослідження соціально-економічних аспектів збитковості внаслідок хронічного обструктивного захворювання легень та бронхіальної астми / О. М. Залінська, В. В Толубаєв // Укр. пульмон. журн. - 2011. - № 1. - С. 33-36.

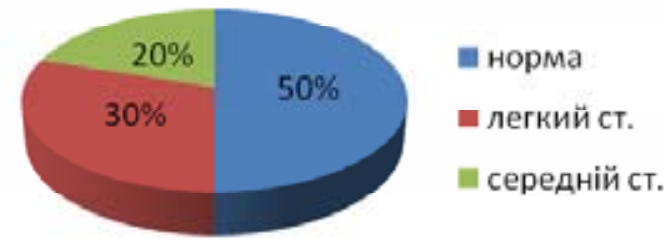

Рис. 2. Розподіл хворих на ХП за ступенем тяжкості анемії.

простежувався вірогідний помірний обернений зв'язок між рівнем НBG в крові та IMT ( $r=-0,37)$. Це підтвердило, що надлишок запасів жиру у хворих групи XП+IXC призводить до поглиблення тяжкості анемії.

Висновки. 1. Трофологічні порушення при ХП швидше прогресували за наявності IXC, про що свідчив розвиток анемії різної глибини у 75 \% пацієнтів (проти 50 \%) з достовірно нижчим рівнем НGB порівняно із групою хворих на ХП.

2. При цьому достовірно знижувався і соматичний пул білка (за рівнем ОМП) на тлі збільшення IMT і товщини ШЖСТ. Тобто, надлишок запасів жиру і збіднення соматичного пулу білка у хворих групи XП+IXC були більш виражені у порівнянні із пацієнтами групи ХП, що вказує на достовірну білкову недостатність.

3. Враховуючи показники обміну заліза можна зробити висновок, що анемія як у групі хворих на ХП в поєднанні з IXC, так і у групі хворих на XП без IXC мала залізодефіцитний характер.

4. Доведено, що надлишок запасів жиру у Хворих групи ХП+ІХС призводив до поглиблення тяжкості анемії.

Перспективи подальших досліджень. У подальшому планується більш детально вивчити особливості трофологічного статусу у хворих на хронічний панкреатит у поєднанні з ішемічною хворобою серця залежно від ступенів тяжкості анемії.

5. Іванюта Л. І. Ендогенна інтоксикація: причини виникнення, значення для клінічного застосування (огдяд) / Л. І Іванюта, О. І. Баранецька // Здоровье женщины. - 2008. - № 1. - С. 252-256.

6. Бабінець Л. С. Роль антропометричних показників для оцінки трофологічного статусу хворих на хронічний панкреатит / Л. С. Бабінець // Кримський терапевтичний журнал - 2008. - № 2. - С. 51-53.

7. Бабінець Л. С. Ентеропанкреатичний синдром і його вплив на трофологічні порушення при хронічному панкреатиті / Л. С. Бабінець, Ю. Я. Коцаба, О. В. Денефіль // Гастроентерологія. - 2013. - № 4. C. 61-65.

8. Сучасні класифікації та стандарти лікування розповсюджених захворювань внутрішніх органів / за ред. 
Огляди літератури, оригінальні дослідження, погляд на проблему

Ю. М. Мостового. - 14-те вид., доп. і переро6. - Вінниця, 2012. - 576 c.

9. Гайдукова С. М. Залізодефіцитна анемія : на-

вчальний посібник для студентів і лікарів / С. М. Гайдукова, С. В. Видиборець, І. В. Колесник. - К. : Науковий світ, 2009. -132 c.

\section{PECULIARITIES OF ANEMIA SYNDROME AS A TROPHOLOGIC MANIFESTATIONS OF INSUFFICIENCY IN CHRONIC PANCREATITIS COMBINED WITH CORONARY HEART DISEASE}

@L. S. Babinets, N. A. Melnyk, L. S. Tsybulska, M. V. Skrypnyk I. Horbachevsky Ternopil State Medical University

SUMMARY. The paper presents the peculiarities of anemic syndrome and changes trophic status in patients with chronic pancreatitis with concomitant coronary heart disease, and investigated the relationship between parameters trophic status and indicators of anemia in such patients.

KEY WORDS: chronic pancreatitis; coronary heart disease; anemic syndrome; trophic insufficiency.

Отримано 1.04.2016 